\title{
Modelowanie transportu materiału zawieszonego w dorzeczu Parsęty z uwzględnieniem zróżnicowanych rozdzielczości danych przestrzennych
}

\author{
Modelling of suspended sediment transport in the Parsęta drainage basin using different \\ spatial data resolutions
}

\author{
Joanna Gudowicz \\ Instytut Geoekologii i Geoinformacji, Uniwersytet im. Adama MickiewiczawPoznaniu; gudowicz@amu.edu.pl
}

Zarys treści: Celem pracy jest przedstawienie modelu hydrologicznego dla dorzecza Parsęty opartego o system informacji geograficznej oraz prezentacja uzyskanych wyników modelowania w zakresie odpływu materiału zawieszonego. W badaniach wykorzystano model SWAT (Soil and Water Assessment Tool) zintegrowany za pomocą aplikacji ArcSWAT z oprogramowaniem ArcGIS. Wyniki poddane zostały ocenie przy zastosowaniu współczynników statystycznych: determinacji $\mathrm{R}^{2}$, efektywności modelu Nasha-Sutcliffa (NSE) oraz współczynnika odchylenia procentowego (PBIAS). Ocenę otrzymanych rezultatów modelowania wykonano pod kątem ich zróżnicowania w zależności od zastosowanych przestrzennych danych wejściowych. Stwierdzono, że najbardziej zgodne z danymi obserwowanymi były wyniki modelowania uzyskane z zastosowaniem danych przestrzennych o najwyższej rozdzielczości.

Słowa kluczowe: modelowanie, transport osadów, SWAT, dane przestrzenne, Parsęta

\begin{abstract}
The aim of this study was to present a GIS-based hydrological model developed for the Parsęta drainage basin and presentation of the results in terms of the suspended sediment outflow. SWAT (Soil and Water Assessment Tool) model integrated by the ArcSWAT application with the ArcGIS software was used in the study. The results were subject to assessment by statistical methods: $\mathrm{R}^{2}$ determination coefficient, Nash-Sutcliffe efficiency coefficient (NSE), percent bias coefficient (PBIAS). The evaluation of the results was performed based on their differentiation depending upon the spatial input data. The most consistent with the observed data were modeling results obtained from the use of high resolution spatial data.
\end{abstract}

Key words: modelling, sediment transport, SWAT, spatial data, Parsęta

\section{Wprowadzenie}

Aktualny rozwój numerycznych modeli hydrologicznych i jakości wody (ang. hydrologic and water quality models, $H / W Q$ ) (Moriasi i in. 2012) umożliwia ich zastosowanie w badaniach procesów erozji gleb i transportu osadów w skali zlewni rzecznej (Merritt i in. 2003, Aksoy, Kavvas 2005, Moriasi i in. 2012, de Vente i in. 2013). W modelach tych implementowane są metody określania wielkości erozji wodnej gleb na stokach oraz ilości materiału dostarczanego ze stoków do koryta rzecznego, a także przepływu wody w korycie. Podstawą wykonywanych symulacji są dane przestrzenne obejmujące przede wszystkim cyfrowy model wysokościowy, jak również dane glebowe, meteorologiczne oraz mapy pokrycia terenu i użytkowania ziemi. Ważnym problem badawczym jest w tym zakresie 
ocena wpływu jakości cyfrowych danych przestrzennych na wyniki modelowanego bilansu wodnego i transportu osadów (Svoray, Atkinson 2013). Numeryczne modele hydrologiczne obejmują zazwyczaj bardzo dużą liczbę parametrów (Zwoliński 2010). Stąd wybór parametrów oraz ich jakość winny być szczególnie ważnym procesem selekcyjnym. Dzięki systemom informacji geograficznej możliwa jest łatwa integracja danych oraz iteracyjność procesu generowania i zmiany tych parametrów na wejściu do modelu. Umożliwiają one zatem analizę wpływu poszczególnych parametrów na ostateczne wyniki modelowania i wybór najbardziej optymalnej struktury modelu pod względem danych wejściowych. Zastosowanie modeli opartych o systemy informacji geograficznej może być szczególnie istotne w badaniach wpływu zmian klimatu na system denudacyjny zlewni. Należy podkreślić, że analizy oddziaływania globalnych zmian klimatu na współczesną ewolucję rzeźby są obecnie niezwykle ważnym problemem badawczym (Goudie 2006, Zwoliński 2011).

Celem pracy było opracowanie modelu hydrologicznego dla dorzecza Parsęty opartego o system informacji geograficznej oraz prezentacja uzyskanych wyników modelowania w zakresie odpływu materiału zawieszonego. Do testowania jakości danych przestrzennych w modelowaniu hydrologicznym wykorzystano model SWAT (Soil and Water Assessment Tool) (Arnold i in. 1998) zintegrowany za pomocą aplikacji ArcSWAT z oprogramowaniem ArcGIS.

\section{Obszar badań}

Badaniami objęto dorzecze Parsęty do profilu zamykającego w Bardach, tj. 25,0 km od ujścia rzeki do Morza Bałtyckiego (ryc. 1). Powierzchnia obszaru badań, 2866 $\mathrm{km}^{2}$, stanowi 93,4\% powierzchni całego dorzecza Parsęty. Badana zlewnia jest reprezentatywna dla obszarów młodoglacjalnych umiarkowanej strefy klimatycznej ze względu na położenie w zasięgu form poglacjalnych, mozaikowy układ litologii utworów powierzchniowych, pokrycia terenu i użytkowania ziemi oraz struktury gleb (Zwoliński 1989, Kostrzewski i in. 1994, Kostrzewski 1998). Cechuje ją także wyrównany reżim przepływów wody, duży stopień bezodpływowości, retencyjności i bezwładności hydrologicznej (Dynowska 1971, Choiński 1988).

W obszarach młodoglacjalnych charakteryzujących się, z geologicznego punktu widzenia, krótkim czasem rozwoju sieci hydrograficznej, nieciągłością warstw geologicznych oraz bardzo urozmaiconą rzeźbą terenu, rozpoznanie krążenia wody jest bardzo utrudnione (Fac-Beneda 2011). Modelowanie tak złożonego geoekosystemu wymaga więc zwrócenia szczególnej uwagi m.in. na takie elementy jak reprezentacja rzeźby terenu, faza podziemna obiegu wody i rola obszarów bezodpływowych.
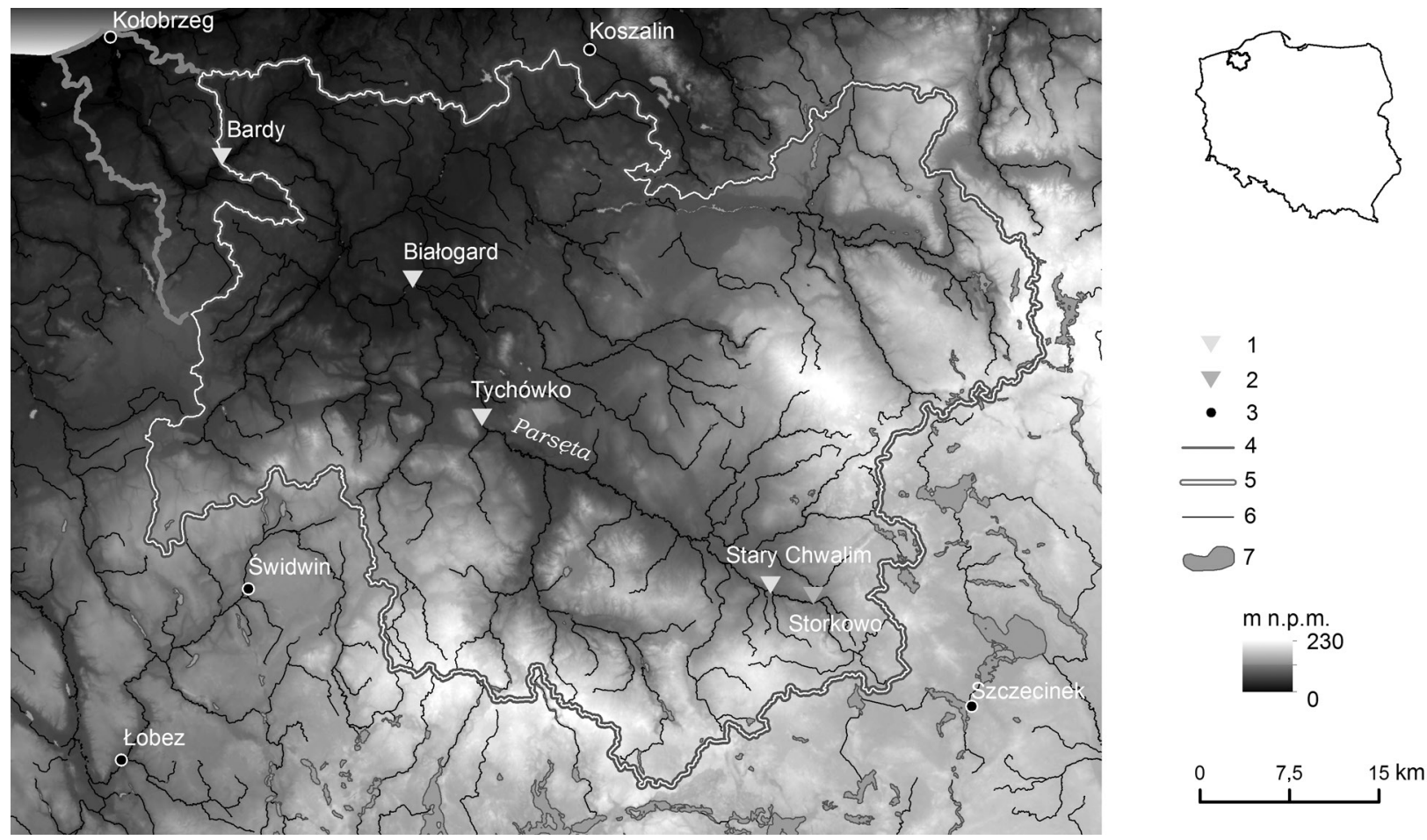

Ryc. 1. Położenie obszaru badań (na podstawie danych DTED2 oraz Mapy Podziału Hydrograficznego Polski)

1 - posterunki hydrometryczne IMGW, 2 - posterunek hydrometryczny UAM, 3 - główne miasta, 4 - wododział dorzecza Parsęty, 5 - obszar badań, 6 - sieć rzeczna, 7 - zbiorniki wodne

Fig. 1. Location of the study area (based on DTED2 data and Map of Hydrographical Division of Poland)

1 - IMGW hydrometric stations, 2 - UAM hydrometric station, 3 - cities, 4 - Parsęta drainage basin, 5 - study area, 6 - rivers, 7 - water bodies 


\section{Metody badań}

Numeryczny model hydrologiczny dla dorzecza Parsęty opracowano w oparciu o program SWAT (Arnold $\mathrm{i}$ in. 1998). W badaniach wykorzystana została wersja modelu SWAT2009 (Neitsch i in. 2011). Model SWAT został stworzony do prognozowania wpływu zmian zagospodarowania zlewni na bilans wody, osadów i biogenów (Arnold i in. 1998). Ze względu na wysoką efektywność obliczeniową, model umożliwia wykonywanie ciągłych symulacji dla bardzo dużych obszarów oraz dla długich przedziałów czasu. Model był testowany i stosowany na wszystkich kontynentach w setkach lokalizacji, w różnych warunkach klimatycznych i glebowych (Gassman i in. 2007, Douglas-Mankin i in. 2010), co przekonuje o jego dużej uniwersalności i możliwości stosowania w zróżnicowanych geoekosystemach. Podstawowym krokiem czasowym modelu jest doba, można go zatem zaliczyć do modeli czasu ciągłego. Ze względu na przyjęcie w modelu jednostek reakcji hydrologicznej (ang. hydrologic response units, HRU) jako podstawowych jednostek obliczeniowych zalicza się go do modeli o parametrach quasi-przestrzennie rozłożonych.

Do podstawowych danych wejściowych do modelu SWAT należy zaliczyć cyfrowy model wysokościowy, mapę pokrycia terenu i użytkowania ziemi, mapę glebową oraz dane meteorologiczne. Do podstawowych zmiennych wyjściowych należy odpływ wody, odpływ osadów i odpływ jonowy, a także ewapotranspiracja dla powierzchni całej zlewni, poszczególnych zlewni cząstkowych i jednostek reakcji hydrologicznej.

$\mathrm{W}$ modelu zaimplementowana jest m.in. metoda szacowania opadu efektywnego SCS-CN (ang. Soil Conservation Service Curve Number, USDA-SCS 1972) oraz metoda szacowania ewapotranspiracji Penmana-Monteitha (Monteith 1965). Erozja wodna gleb na powierzchniach stokowych obliczana jest ze zmodyfikowanego uniwersalnego równania strat glebowych (Modified Universal Soil Loss Equation, MUSLE), które opisane jest następującym wzorem (Williams 1975):

$$
\begin{gathered}
\text { sed }=11,8 \cdot\left(Q_{\text {surf }} \cdot q_{\text {peak }} \cdot \text { area }_{h r u}\right) 0,56 \cdot K_{U S L E} \\
\cdot C_{U S L E} \cdot P_{U S L E} \cdot L S_{U S L E} \cdot C F R G
\end{gathered}
$$

gdzie:

sed - ilość wyerodowanych osadów [t],

$Q_{\text {surf }}$ - wielkość spływu powierzchniowego [mm],

$q_{\text {peak }}-$ kulminacja spływu $\left[\mathrm{m}^{3} \mathrm{~s}^{-1}\right]$,

area $_{\text {hru }}$ - powierzchnia HRU [ha],

$K_{U S L E}-$ współczynnik erozyjności gleb [-],

$C_{U S L E}$-współczynnik rodzaju upraw i użytkowania terenu

$[-]$,

$P_{U S L E}-$ współczynnik zabiegów przeciwerozyjnych [-],

$L S_{U S L E}$ - współczynnik topograficzny długości i nachylenia stoku $[-]$,

$C F R G$ - współczynnik materiału gruboziarnistego [-].
Transport osadów jest funkcją procesów erozji i depozycji. Obejmuje on system stokowy i system korytowy. W transporcie stokowym skład uziarnienia erodowanych cząstek jest estymowany na podstawie składu granulometrycznego osadów podłoża (Foster i in. 1980). Transport osadów z systemu stokowego do systemu korytowego jest sterowany przez natężenie spływu powierzchniowego. Wielkość ładunku osadów docierających do koryta uzyskiwana jest poprzez odjęcie od ilości wyerodowanego materiału (na podstawie równania MUSLE) opóźnienia oraz osadów zatrzymanych przez szatę roślinną, w stawach czy oczkach wodnych (Neitsch i in. 2011). Wielkość ładunku osadów docierających do koryta obliczana jest na podstawie wzoru:

$$
\operatorname{sed}=\left(\operatorname{sed}^{\prime}+\operatorname{sed}_{\text {stor },-1}\right) \cdot\left(1-\exp \left[\frac{- \text { surlag }}{t_{\text {conc }}}\right]\right)
$$

gdzie:

sed - ilość osadów dostarczana do koryta w dniu $i[\mathrm{t}]$, sed' - ilość osadów wyerodowanych z obszaru danego HRU w dniu $i[\mathrm{t}]$,

sed $_{\text {stor } ;-1}-$ ilość osadów wyerodowanych z obszaru danego HRU zatrzymanych $\mathrm{w}$ dniu $i^{-1}[\mathrm{t}]$,

surlag - współczynnik opóźnienia spływu powierzchniowego [-],

$t_{\text {conc }}$ - czas koncentracji dla danego HRU [h].

W korycie rzecznym procesy erozji i depozycji zależą od energii cieku, ekspozycji brzegów i dna koryta na siłę erozyjną cieku oraz materiału budującego brzegi i dno koryta (Neitsch i in. 2011). Do symulacji transportu osadów w korycie jako podstawowe stosowane jest zaadoptowane przez Williamsa (1980) równanie energii cieku (Bagnold 1977). Maksymalna ilość osadów jaka może być transportowana $\mathrm{z}$ jednego segmentu cieku obliczana jest wg wzoru:

$$
\operatorname{conc}_{s e d, c h, m x}=c_{s p}\left(\frac{q_{c h, p k}}{A_{c h}}\right)^{s p \exp }
$$

gdzie:

conc $_{\text {sed,ch,mx }}$ - maksymalna koncentracja materiału zawieszonego $\left[\mathrm{t} \mathrm{m}^{-3}\right]$,

$c_{s p}$ - współczynnik definiowany przez użytkownika $[-]$,

$q_{c h, p k}-$ maksymalny przepływ wody $\left[\mathrm{m}^{3} \mathrm{~s}^{-1}\right]$,

$A_{c h}$ - powierzchnia przekroju poprzecznego $\left[\mathrm{m}^{2}\right]$

$s p$ exp - wykładnik funkcji definiowany przez użytkownika $[-]$.

Optymalne wartości współczynnika $c_{s p}$ oraz wykładnika funkcji sp exp mogą być określone na etapie kalibracji modelu. Kalibrowane parametry to odpowiednio SPCON oraz SPEXP. W przeprowadzonych badaniach wartości tych parametrów określono właśnie podczas kalibracji na podstawie danych pomiarowych. Otrzymana na podstawie powyższego równania koncentracja materiału zawieszonego dla danego odcinka rzeki jest porównywana do wartości koncentracji symulowanej dla danej chwili czasu t. Jeżeli wartość początkowa jest większa - wtedy dominującym procesem jest depozycja, jeżeli natomiast mniejsza - wtedy dominującym procesem jest erozja. 


\section{Konstrukcja modelu SWAT dla dorzecza Parsęty}

W celu oceny wpływu jakości danych przestrzennych na wyniki modelowanego bilansu wodnego i transportu osadów do opracowania modelu hydrologicznego dla dorzecza Parsęty pozyskano dane z różnych źródeł. Podstawowym zestawem danych był cyfrowy model wysokościowy (DEM). Wykorzystano trzy źródła danych (tab. 1):

- DEM utworzony na podstawie interpolacji wartości poziomic pochodzących z wektoryzacji map topograficznych w skali 1:10 000 (rozdzielczość $10 \mathrm{~m}$ );

- DEM pozyskany $\mathrm{z}$ danych DTED2 (rozdzielczość $30 \mathrm{~m})$;

- DEM pozyskany z danych SRTM w wersji czwartej (rozdzielczość $90 \mathrm{~m}$ ) (Jarvis i in. 2008).

Odpowiednio do cyfrowych modeli wysokościowych wykorzystano również trzy źródła map glebowych (tab. 1):

- mapy glebowo-rolnicze Instytutu Uprawy Nawożenia i Gleboznawstwa w Puławach pozyskane z bazy Wojewódzkiego Ośrodka Dokumentacji Geodezyjnej i Kartograficznej w Szczecinie (skala 1:25 000), które uzupełniono w oparciu o dane litologiczne ze szczegółowych map geologicznych (skala 1:50 000) pozyskane z Państwowego Instytutu Geologicznego - Państwowego Instytutu Badawczego;

- dane pozyskane z bazy gleb Harmonized World Soil Database (HWSD) (skala 1:000 000) (FAO/IIASA/ ISRIC/ISSCAS/JRC 2012);

- dane pozyskane z bazy FAO-UNESCO Digital Soil Map of the World (skala 1:5 000 000) (FAO-UNESCO 2003). Model SWAT wymaga określenia dla wydzieleń wyszczególnionych na mapach dla poszczególnych poziomów glebowych parametrów fizycznych takich jak grupa hydrologiczna gleby, maksymalna głębokość ukorzenienia, głębokość profilu glebowego, gęstość objętościowa, nasycona przewodność hydrauliczna, zawartość węgla organicznego, zawartość iłu, zawartość pyłów, zawartość piasków, zawartość części szkieletowych, współczynnik erozyjności gleby. Właściwości fizyczne określono na podstawie parametrów danych zawartych w wykorzystywanych bazach danych glebowych oraz na podstawie literatury (Ignar 1988, Renard i in. 1997).

W badaniach zastosowano dane meteorologiczne pozyskane z Instytutu Meteorologii i Gospodarki Wodnej - Państwowego Instytutu Badawczego z wielolecia 1966-2010. Dane pochodziły z 4 stacji meteorologicznych (Koszalin, Kołobrzeg, Resko, Szczecinek) oraz 10 posterunków opadowych. Wykorzystane zostały następujące zmienne meteorologiczne: opad atmosferyczny [mm], minimalna i maksymalna temperatura powietrza $\left[{ }^{\circ} \mathrm{C}\right]$, średnia prędkość wiatru [ $\mathrm{m} \mathrm{s}^{-1}$, średnia wilgotność względna [\%]. W celu uwzględnienia zmian pokrycia terenu i użytkowania ziemi jakie zachodziły w zlewni $\mathrm{w}$ analizowanym wieloleciu zastosowano mapy pokrycia terenu i użytkowania ziemi z czterech horyzontów czasowych. Źródłem danych była baza CORINE Land Cover dla lat 1990, 2000 i 2006 oraz dane opracowane na podstawie wektoryzacji mapy
Tabela 1. Dane przestrzenne projektów SWAT dla obszaru zlewni Parsęty

Table 1. Spatial data of the SWAT projects for the Parsęta river basin

\begin{tabular}{lccc}
\hline \multicolumn{1}{c}{ Gleby } & DEM $_{\text {TOPO }}$ & DEM $_{\text {DTED2 }}$ & DEM $_{\text {SRTM }}$ \\
\hline $\begin{array}{l}\text { Baza IUNG } \\
(1: 25000)\end{array}$ & SWAT_1 & SWAT_4 & SWAT_7 \\
\hline $\begin{array}{l}\text { Baza HWSD } \\
(1: 1000000)\end{array}$ & SWAT_2 & SWAT_5 & SWAT_8 \\
\hline $\begin{array}{l}\text { Baza FAO-UNESCO } \\
(1: 5000 \text { 000 })\end{array}$ & SWAT_3 & SWAT_6 & SWAT_9 \\
\hline
\end{tabular}

topograficznej w skali 1:100 000 (rok 1975). Przygotowane mapy pokrycia terenu i użytkowania ziemi wymagały reklasyfikacji do klas, które zawarte są w bazie danych parametrów modelu SWAT.

Zgromadzone zestawy danych przestrzennych posłużyły do utworzenia projektów modelu SWAT, które charakteryzowały się odmiennymi danymi wysokościowymi oraz glebowymi (por. tab. 1). We wszystkich projektach wejściowe dane pokrycia terenu i użytkowania ziemi oraz dane meteorologiczne były takie same. Opracowanie różnych projektów umożliwiło ocenę wpływu jakości wejściowych danych wysokościowych oraz glebowych na wyniki symulacji bilansu wodnego oraz transportu materiału zawieszonego. Weryfikacja wyników oparta była o zastosowanie współczynników statystycznych: determinacji $\mathrm{R}^{2}$, efektywności modelu Nasha-Sutcliffa (NSE) oraz współczynnika odchylenia procentowego (PBIAS).

Kalibrację struktur modelu SWAT wykonano w oprogramowaniu SWAT-CUP4 (Abbaspour 2012) na podstawie danych pomiarowych z posterunków hydrometrycznych w Tychówku, Białogardzie i Bardach (ryc. 1). W tym celu wykorzystano dane pozyskane z Instytutu Meteorologii i Gospodarki Wodnej - Państwowego Instytutu Badawczego dla lat 1966-2010. Kalibrację opracowano z wykorzystaniem procedury Sequential Uncertainty Fitting (SUFI2) (Abbaspour i in. 2004).

\section{Wyniki badań}

Symulacje obiegu wody w zlewni Parsęty przeprowadzono dla okresu 1966-2010, gdzie lata 1966-1968 przeznaczone były na okres dostosowywania modelu (ang. warm-up period), lata 1969-1995 na kalibrację, a lata 1996-2010 na walidację modelu. W pierwszym kroku oceny wyników symulacji weryfikacji poddano wartości podstawowych elementów bilansu wodnego, na które składały się wartości dotyczące sumy opadu i odpływu całkowitego. Wyniki weryfikowano dla obszaru całego dorzecza Parsęty jako wartości średnie roczne z analizowanych wieloleci okresu kalibracji oraz okresu walidacji. Stwierdzono różnice w porównaniu do danych pomiarowych na poziomie od kilku do kilkunastu procent w zależności od przyjętej struktury modelu SWAT.

Kolejnym etapem analizy wyników symulacji była weryfikacja serii czasowych. Weryfikację wyników sy- 
mulacji odpływu materiału zawieszonego przeprowadzono na podstawie danych z posterunku hydrometrycznego zamykającego dorzecze Parsęty w Bardach z lat 19691983 oraz 1989-2010. Ocenę modeli według poszczególnych projektów wykonano zarówno dla okresów kalibracji jak i walidacji.

$\mathrm{Na}$ weryfikację wyników symulacji odpływu zawiesiny z dorzecza Parsęty ma wpływ niekompletność pomiarów służby hydrologicznej. Dla profilu zamykającego w Bardach nie ma bowiem jednolitej, ciągłej serii pomiarów dobowych dla analizowanego wielolecia. Przy weryfikacji modelu brano zatem pod uwagę dostępne wartości, uzupełniając pozostałe kodem braku danych.

W tabeli 2 przedstawiono współczynniki oceny rocznych ładunków materiału zawieszonego odprowadzanego z dorzecza Parsęty. Należy stwierdzić, że otrzymane wartości statystyk według przyjętego kryterium Sarma i in. (1973) oraz Singha i in. (2004) są zróżnicowane w zależności od projektów SWAT. Według współczynnika determinacji wyniki uznać można za dobre i bardzo dobre w okresie kalibracji i walidacji. Oznaczają one, że przyjęte zmienne w symulacjach objaśniają zmiany ładunku materiału zawieszonego w granicach 60-80\%. Wartości współczynnika NSE mieszczą się w zakresie 0,5-0,7, co oznacza zgodnie z przyjętym kryterium oceny, że wszystkie wyniki uznać należy za poprawne. Odnosząc się do wartości współczynnika odchylenia procentowego (PBIAS) należy stwierdzić, że wartości były zaniżone w stosunku do danych pomiarowych. Pod względem PBIAS wszystkie wyniki należy uznać za poprawne. Najmniejsze różnice na poziomie $13-15 \%$ wystąpiły w projekcie SWAT 1. Przedstawiona charakterystyka oceny projektów SWAT (tab. 2) odnosi się zarówno do okresu kalibracji, jak i do okresu walidacji modeli, co świadczy o poprawnym określeniu ram czasowych okresu kalibracji i walidacji, dobrym doborze wartości parametrów podczas procedury kalibracji oraz stabilności przyjętych struktur modelu SWAT.
Tabela 2. Statystyki oceny symulowanych rocznych wartości odpływu materiału zawieszonego dla profilu zamykającego zlewnię Parsęty

Table 2. Statistics evaluation of the simulated annual suspended sediment outflow for the outlet of the Parsęta river basin

\begin{tabular}{lcccccc}
\hline \multirow{2}{*}{ Projekt } & \multicolumn{3}{c}{ Okres kalibracji } & \multicolumn{3}{c}{ Okres walidacji } \\
\cline { 2 - 7 } & $\mathrm{R}^{2}$ & NSE & PBIAS & $\mathrm{R}^{2}$ & NSE & PBIAS \\
\hline SWAT_1 & 0,78 & 0,70 & 13,46 & 0,76 & 0,70 & 14,74 \\
\hline SWAT_2 & 0,77 & 0,69 & 16,10 & 0,74 & 0,67 & 17,25 \\
\hline SWAT_3 & 0,65 & 0,55 & 25,47 & 0,63 & 0,54 & 26,41 \\
\hline SWAT_4 & 0,78 & 0,70 & 15,06 & 0,77 & 0,70 & 16,23 \\
\hline SWAT_5 & 0,74 & 0,66 & 18,12 & 0,71 & 0,64 & 19,98 \\
\hline SWAT_6 & 0,63 & 0,54 & 28,09 & 0,63 & 0,53 & 29,35 \\
\hline SWAT_7 & 0,68 & 0,60 & 19,00 & 0,66 & 0,59 & 21,41 \\
\hline SWAT_8 & 0,67 & 0,59 & 22,26 & 0,63 & 0,60 & 24,88 \\
\hline SWAT_9 & 0,59 & 0,51 & 31,78 & 0,58 & 0,50 & 32,26
\end{tabular}

Uzyskane statystyki oceny wskazują na zróżnicowanie wyników w zależności od wykorzystanych danych wejściowych w poszczególnych projektach. Największą zgodność danych symulowanych z pomiarowymi uzyskano dla projektu SWAT_1, w którym operowano na danych wysokorozdzielczych opartych o warstwę glebową opracowaną na podstawie map glebowo-rolniczych oraz DEM w rozdzielczości $10 \mathrm{~m}$. Zastosowanie danych o małej rozdzielczości w projekcie SWAT 9, gdzie wykorzystywany był DEM o rozdzielczości 90 m oraz mapa glebowa w skali 1:5 000000 wpłynęło na najsłabsze wyniki. Wpływ na otrzymane rezultaty mógł mieć proces delimitacji sieci rzecznej i zlewni cząstkowych w oparciu o wybrane źródła danych DEM (Gudowicz 2016), jak i reprezentacja wydzieleń glebowych. Mapa FAO-UNESCO obejmowała dla badanego obszaru jedynie trzy wydzielenia, co nie było w pełni wystarczające dla odzwierciedlenia zróżnicowania przestrzennego gleb.

Na rycinie 2 przedstawiono porównanie pomiarowych i symulowanych rocznych ładunków materiału zawieszonego dla projektów, które różniły się zarówno wejściową mapą glebową jak i danymi wysokościowymi.

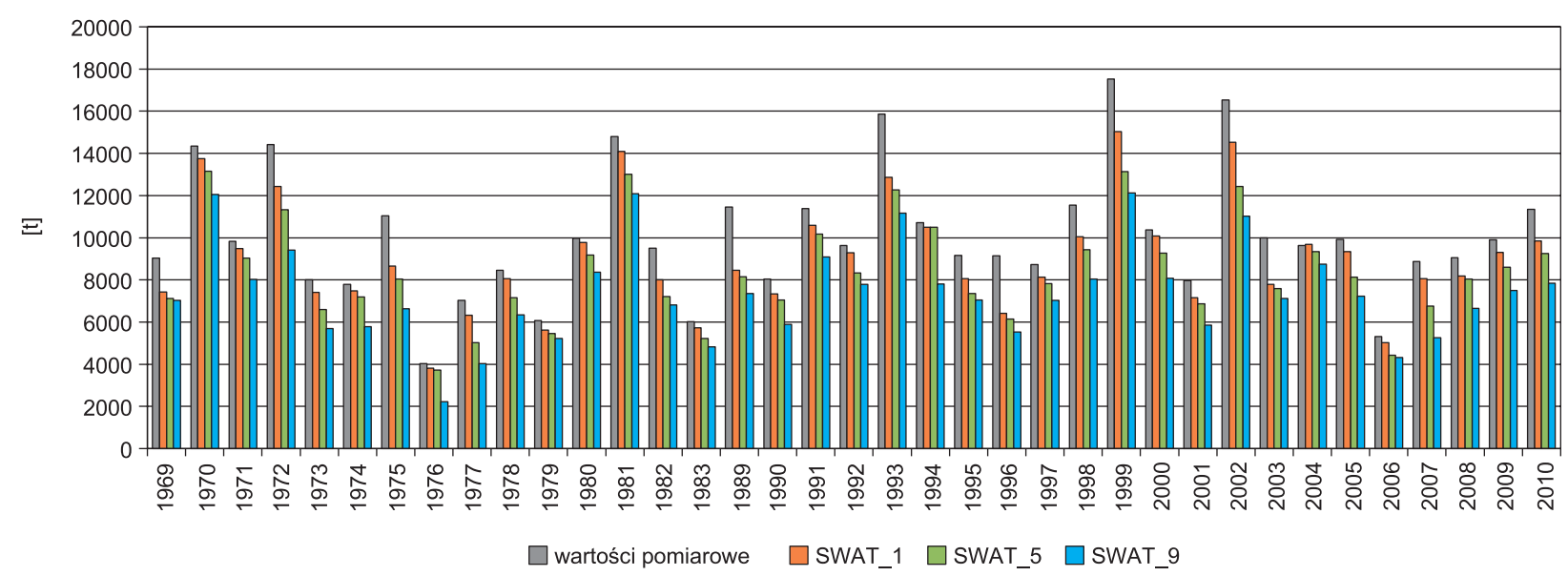

Ryc. 2. Porównanie pomiarowych i symulowanych wartości rocznych ładunków materiału zawieszonego dla profilu hydrometrycznego w Bardach

Fig. 2. Comparison of measured and simulated values of annual suspended sediment outflow for the outlet of the Parsęta river basin in Bardy 
Analizując symulowane wartości odpływu materiału zawieszonego uzyskane dla profilu zamykającego zlewnię (ryc. 2) należy stwierdzić, że różnice uzyskanych wyników według opracowanych projektów SWAT nie były stałe, a zmieniały się w poszczególnych latach. Największe różnice odnotować należy w roku 1975, 1989, 1993, 1996, 1999, 2002 i 2003. Wyniosły one w tych latach w projekcie SWAT_1 średnio 21\%,w projekcie SWAT_5
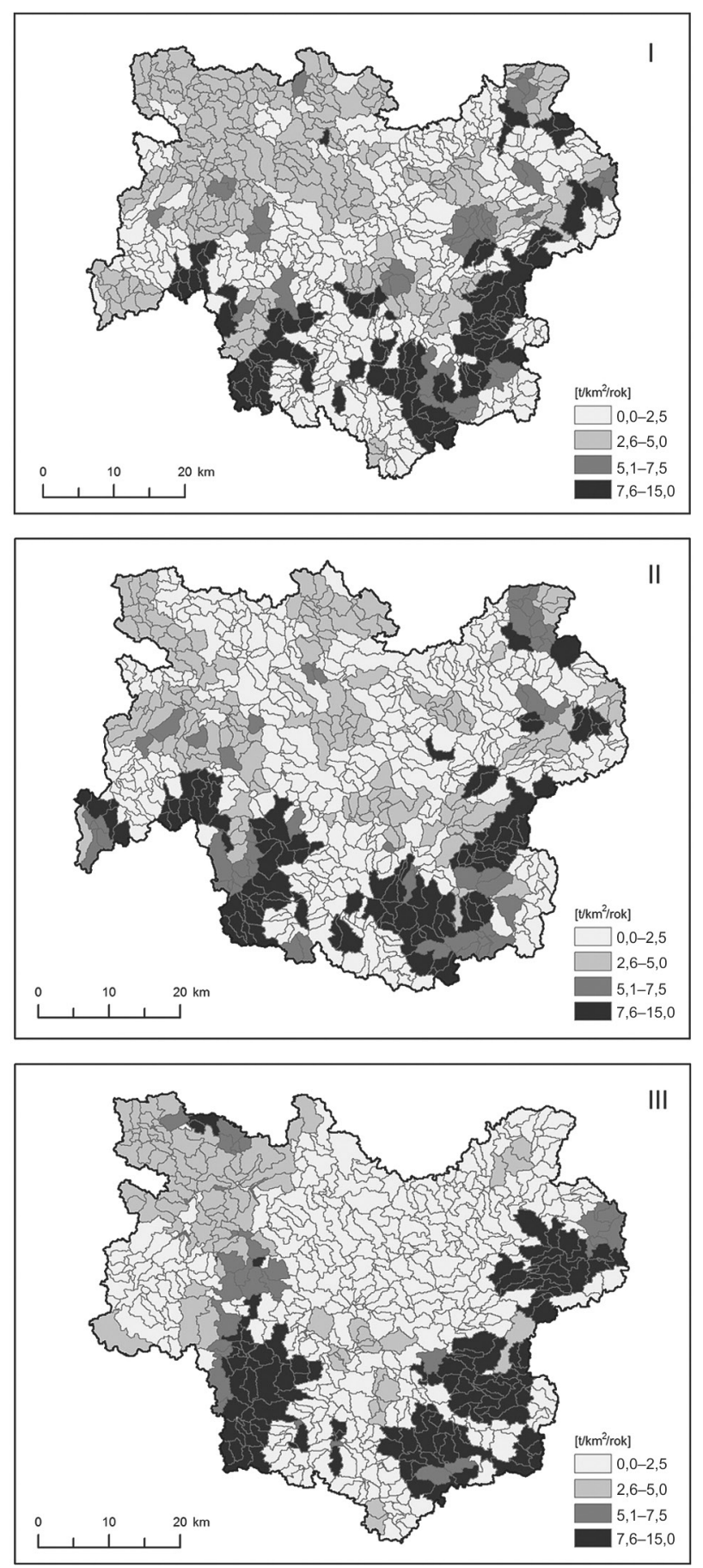

Ryc. 3. Symulowana średnia roczna wartość wskaźnika denudacji mechanicznej w zlewni Parsęty

I - SWAT 1, II - SWAT 5, III - SWAT 9

Fig. 3. Simulated average annual mechanical denudation rate in Parsęta river basin

I - SWAT_1, II - SWAT_5, III - SWAT_9
$-26 \%$, a w projekcie SWAT $9-38 \%$. Na zaniżone wielkości odpływu zawiesiny w latach 1975, 1989, 1996 i 2003 może mieć wpływ to, iż były to lata suche, w których znacznie niedoszacowane były objętości odpływu wody. W roku 1993, 1999 oraz 2002 wystąpiły natomiast wysokie ładunki odprowadzanego materiału w analizowanym wieloleciu, które zostały niedoszacowane przez model. Jednocześnie można zauważyć, że różnice między projektami SWAT_1 i SWAT_5 nie były tak znaczne, jak w stosunku do projektu SWAT 9.

Uzyskane wyniki symulacji pozwoliły na analizę zróżnicowania przestrzennego transportu osadów w dorzeczu Parsęty. Wykonano mapy przestrzennego rozkładu wielkości denudacji mechanicznej w układzie zlewni cząstkowych. Na rycinie 3 ujęto wartości średnie roczne wskaźnika denudacji mechanicznej. Większość zlewni cząstkowych mieści się w zakresie $0-5 \mathrm{t} \mathrm{km}^{-2} \mathrm{a}^{-1}$. Uzyskane wyniki korespondują z oszacowaną przez Brańskiego i Banasika (1996) wielkością denudacji mechanicznej dla obszaru dorzecza Parsęty, która wyniosła poniżej $5 \mathrm{t} \mathrm{km}{ }^{-2}$ $\mathrm{a}^{-1}$. Jednak wartości maksymalne mogą dochodzić do 15 $\mathrm{t} \mathrm{km}^{-2} \mathrm{a}^{-1}$. Analizując wartości średnie miesięczne należy stwierdzić, że większość obszaru badań charakteryzuje się wartościami w zakresie $0,0-0,3 \mathrm{t} \mathrm{km}^{-2} \mathrm{a}^{-1}$.

Uzyskany obraz przestrzenny tempa denudacji mechanicznej wykazuje duży związek z pokryciem terenu i użytkowaniem ziemi w obrębie badanej zlewni. Zlewnie cząstkowe o niskich wartościach denudacji pokrywają się z terenami lasów, natomiast wyższe wartości charakteryzują zlewnie położone na terenach rolniczych. Zauważalny jest także związek z ukształtowaniem rzeźby terenu. Zlewnie o wyższych wartościach wskaźnika denudacji w zakresie $5-15 \mathrm{t} \mathrm{km}^{-2} \mathrm{a}^{-1}$ położone są na obszarach o większych spadkach terenu. Wg projektu SWAT_1 oraz SWAT_5 zróżnicowanie wskaźnika denudacji w obrębie dorzecza Parsęty jest większe w porównaniu do projektu SWAT_9, gdzie największą powierzchnię zajmują zlewnie cząstkowe o wartościach $\mathrm{w}$ zakresie $0-2,5 \mathrm{t} \mathrm{km}^{-2} \mathrm{a}^{-1}$. W projekcie SWAT 1 można zauważyć większy udział obszarów o wartościach wskaźnika denudacji w zakresie $2,6-5 \mathrm{t} \mathrm{km}{ }^{-2} \mathrm{a}^{-1} \mathrm{w}$ porównaniu do pozostałych projektów.

\section{Dyskusja wyników}

Symulacje ładunków materiału zawieszonego odprowadzanych ze zlewni z wykorzystaniem SWAT nie są poddawane ocenie tak często jak odpływ wody. Jednak liczne publikacje wskazują, że model jest w stanie poprawnie prognozować ładunki zawiesiny, zwłaszcza miesięczne i roczne (Gassman i in. 2007, Douglas-Mankin i in. 2010). Wśród prac, gdzie modelowanie wykonane było dla dużych zlewni wskazać można m.in. badania Saleha $\mathrm{i}$ in. (2000). Wykonali oni modelowanie transportu materiału zawieszonego dla zlewni o powierzchni $932,5 \mathrm{~km}^{2}$ stwierdzając dobrą zgodność wartości średnich miesięcznych ładunków. Jednak wyniki dobowe obarczone były dużym błędem. Santhi i in. (2001) przeprowadzili badania 
dla zlewni o powierzchni $4277 \mathrm{~km}^{2}$. Uzyskano dobre wyniki dla danych miesięcznych oprócz marca.

Autorzy wskazują, że wyniki modelu SWAT są zależne od rozdzielczości wykorzystanych danych wejściowych (Cotter i in. 2003, Chaplot 2005, Di Luzio i in. 2005, Geza, McCray 2008, Kim i in. 2012, Beeson $i$ in. 2014). Chaplot (2005) przeanalizował cyfrowe modele wysokościowe o rozdzielczościach z przedziału od 20 do $500 \mathrm{~m}$. Rekomenduje on stosowanie DEM o rozdzielczości do $50 \mathrm{~m}$ w symulacjach SWAT. Wskazuje także, że DEM ma większy wpływ na wartości ładunków materiału zawieszonego oraz azotanów, niż na wartości odpływu wody. Może być to związane z zastosowaniem w modelu metody SCS-CN przy symulacji odpływu wody. Wskaźnik topograficzny ma tutaj mniejszą wagę w obliczeniach związanych z intercepcją, infiltracją i retencją. W obliczeniach odprowadzanych ładunków zawiesiny stosowane jest w modelu równanie MUSLE, w którym parametry morfometryczne zlewni mają istotne znaczenie. Pominięcie mniejszych form rzeźby terenu i wygładzenie powierzchni niskorozdzielczych cyfrowych modeli wysokościowych przekłada się zatem na wyniki symulacji. Chaplot (2005) potwierdził także wpływ rozdzielczości danych glebowych na rezultaty modelowania w zakresie materiału zawieszonego. $\mathrm{W}$ tym przypadku również zastosowanie zgeneralizowanych map glebowych skutkowało słabszą oceną modeli niż przy wykorzystaniu danych w skali 1:25000.

Uzyskanie dobrej zgodności danych symulowanych i pomiarowych w zakresie materiału zawieszonego możliwe jest po przeprowadzeniu kalibracji modelu, zwłaszcza przy zastosowaniu danych wejściowych o niskiej rozdzielczości (Vigiak i in. 2015). Wykonane badania potwierdzają konieczność skalibrowania modelu w oparciu o dane pomiarowe. Należy także podkreślić, iż do uzyskania poprawnych wyników w zakresie symulacji transportu osadów w modelu SWAT należy stosować dane wysokorozdzielcze. Różnice współczynników statystycznych pomiędzy analizowanymi projektami były w przypadku zawiesiny znacznie większe niż w przypadku porównania ocen jedynie dla odpływu wody.

\section{Podsumowanie}

Wyniki symulacji uzyskane z trzech opracowanych struktur modelu SWAT dla dorzecza Parsęty były poprawne i charakteryzowały się wysokimi wartościami współczynników oceny statystycznej. Otrzymanie tak dobrych rezultatów było możliwe dzięki przeprowadzeniu procedury kalibracji w oparciu o dane pomiarowe. Jednocześnie stwierdzono, że najbardziej zgodne z danymi obserwowanymi były wyniki uzyskane $\mathrm{z}$ zastosowaniem danych przestrzennych o wysokiej rozdzielczości. Model oparty o dane niskorozdzielcze cechował się natomiast największym błędem. Opracowana baza danych i struktury modelu mogą posłużyć w dalszym etapie prac do przeprowadzenia symulacji uwzględniających scenariusze zmian klimatycznych oraz scenariusze zmian pokrycia terenu i użytkowania ziemi.

\section{Podziękowania}

Praca naukowa finansowana ze środków na naukę w latach 2009-2012 jako projekt badawczy Ministerstwa Nauki i Szkolnictwa Wyższego nr N N306 040936.

\section{Literatura}

Abbaspour K.C., Johnson A., van Genuchten M.Th., 2004. Estimating uncertain flow and transport parameters using a sequential uncertainty fitting procedure. Vadose Zone Journal 3(4): 1340-1352.

Abbaspour K.C., 2012. SWAT-CUP 2012: SWAT Calibration and Uncertainty Programs - A User Manual. Eawag, 103.

Aksoy H., Kavvas M.L., 2005. A review of hillslope and watershed scale erosion and sediment transport models. Catena 64: 247-271.

Arnold J.G., Srinivasan R., Muttiah R.S., Williams J.R., 1998. Large area hydrologic modeling and assessment: Part I. Model development. Journal of American Water Resources Association 34(1): 73-89.

Bagnold R.A., 1977. Bedload transport in natural rivers. Water Resources Research 13: 303-312.

Beeson P.C., Sadeghi A.M., Lang M.W., Tomer M.D., Daughtry C.S.T., 2014. Sediment delivery estimates in water quality models altered by resolution and source of topographic data. Journal of Environmental Quality 43: 26-36.

Brański J., Banasik K., 1996. Sediment yields and denudation rates in Poland. W: Erosion and Sediment Yield: Global and Regional Perspectives, Proceedings of the Exeter Symposium, July 1996, IAHS Publ. 236.

Chaplot V., 2005. Impact of DEM mesh size and soil map scale on SWAT runoff, sediment, and NO3-N loads predictions. Journal of Hydrology 312: 207-222.

Choiński A., 1998. Warunki obiegu wody w dorzeczu Parsęty. W: Funkcjonowanie geoekosystemów zlewni rzecznych 1. Środowisko przyrodnicze dorzecza Parsęty - stan badań, zagospodarowanie, ochrona, A. Kostrzewski (red.), Wyd. Uczelniane Polit. Koszalińskiej, Poznań: 36-51.

Cotter A.S., Chaubey I., Costello T.A., Soerens T.S., Nelson M.A., 2003. Water quality model output uncertainty as affected by spatial resolution of input data. Journal of the American Water Resource Association 39(4): 977-986.

de Vente J., Poesen J., Verstraeten G., Govers G., Vanmaercke M., Van Rompaey A., Arabkhedri M., Boix-Fayos C., 2013. Predicting soil erosion and sediment yield at regional scales: Where do we stand? Earth-Science Reviews 127: 16-29.

Di Luzio M., Arnold J.G., Srinivasan R., 2005. Effect of GIS data quality on small watershed streamflow and sediment simulations. Hydrological Processes 19(3): 629-650.

Douglas-Mankin K.R., Srinivasan R., Arnold J.G., 2010. Soil and Water Assesment Tool (SWAT) model: Current developments and applications. Transactions of the ASABE 53(5): 1423-1431.

Dynowska I., 1971. Typy reżimów rzecznych w Polsce. Zesz. Nauk. UJ, Pr. Geogr., 28.

Fac-Beneda J., 2011. Młodoglacjalny system hydrograficzny. Wydawnictwo Uniwersytetu Gdańskiego, Gdańsk, 216.

FAO/UNESCO, 2003. Digital Soil Map of the World and Derived Soil Properties. Rev. 1. (CD Rom). Online: http://www.fao.org/catalog/ what new-e.htm.

FAO/IIASA/ISRIC/ISSCAS/JRC, 2012. Harmonized World Soil Database (version 1.2). FAO, Rome, Italy and IIASA, Laxenburg, Austria.

Foster G.R., Lane L.J., Nowlin J.D., Laflen J.M., Young R.A., 1980. A model to estimate the sediment yield from file-sized areas: Development of model. CP-80-10, Intl. Inst. For Applied Systems Analysis, A-231, Laxenburg, Austria. 
Geza M., McCray J.E., 2008. Effects of soil data resolution on SWAT model stream flow and water quality predictions. Journal of Environmental Management 88: 393-406.

Gassman P.W., Reyes M.R., Green C.H., Arnold J.G., 2007. The Soil and Water Assessment Tool: historical development, applications, and future research directions. Transactions of ASABE (American Society of Agricultural and Biological Engineers) 50(4): 1211-1250.

Goudie A.S., 2006. Global warming and fluvial geomorphology. Geomorphology 79: 384-394.

Gudowicz J., 2016. Wpływ jakości danych przestrzennych na wyniki modelowania obiegu wody w dorzeczu Parsęty. Roczniki Geomatyki 4(74): 437-446.

Ignar S., 1988. Metoda SCS i jej zastosowanie do wyznaczania opadu efektywnego. Przegląd Geofizyczny 33(4): 451-455.

Jarvis A., Reuter H.I., Nelson A., Guevara E., 2008. Hole-filled seamless SRTM data V4. International Centre for Tropical Agriculture (CIAT). Online: http://srtm.csi.cgiar.org.

Kim J., Noh J., Son K., Kim I., 2012. Impacts of GIS data quality on determination of runoff and suspended sediments in the Imha watershed in Korea. Geosciences Journal 16: 181-192.

Kostrzewski A., 1998. Struktura krajobrazowa dorzecza Parsęty w oparciu o dotychczasowe podziały fizyczno-geograficzne. W: Funkcjonowanie geoekosystemów zlewni rzecznych. Środowisko przyrodnicze dorzecza Parsęty, stan badań, zagospodarowanie, ochrona, A. Kostrzewski (red.), Wydawnictwo Naukowe Bogucki, Poznań: 131-141.

Kostrzewski A., Mazurek M., Zwoliński Zb., 1994. Dynamika transportu fluwialnego górnej Parsęty jako odbicie funkcjonowania systemu zlewni. Stowarzyszenie Geomorfologów Polskich, Wydawnictwo Naukowe Bogucki, Poznań: 1-165.

Merritt W.S., Letcher R.A., Jakeman A.J., 2003. A review of erosion and sediment transport models. Environmental Modeling \& Software 18: 761-799.

Monteith J.L., 1965. Evaporation and the environment. In: The State and Movement of Water in Living Organisms, Proc. 19th Symp. Swansea, U.K.: Society of Experimental Biology, Cambridge University Press.

Moriasi D.N., Wilson B.N., Douglas-Mankin K.R., Arnold J.G., Gowda P.H., 2012. Hydrologic and water quality models: use, calibration, and validation. Transactions of the ASABE 55(4): 1241-1247.

Neitsch S.L., Arnold J.G., Kiniry J.R., Williams J.R., 2011. Soil and Water Assessment Tool theoretical documentation, version 2009.
Temple, Tex.: USDA-ARS Grassland, Soil and Water Research Laboratory.

Renard K.G., Foster G.R., Weesies G.A., Porter J.P., 1991. RUSLE: Revised Universal Soil Loss Equation. Journal of Soil and Water Conservation 46(1): 30-33.

Saleh A., Arnold J.G., Gassman P.W., Hauck L.W., Rosenthal W.D., Williams J.R., McFarland A.M.S., 2000: Application of SWAT for the upper North Bosque River watershed. Transactions ASAE 43(5): 1077-1087.

Santhi C., Arnold J.G., Williams J.R., Dugas W.A., Srinivasan R., Hauck L.M., 2001: Validation of the SWAT model on a large river basin with point and nonpoint sources. Journal of the American Water Resources Association 37(5): 1169-1188.

Sarma P.B.S., Delleur J.W., Rao A.R., 1973. Comparison of rainfall-runoff models for urban areas. Journal of Hydrology 18(3-4): 329-347.

Singh J., Knapp H.V., Demissie M., 2004. Hydrological modeling of the Iroquois river watershed using HSPF and SWAT. Journal of the American Water Resources Association 41: 343-360.

Svoray T., Atkinson P.M., 2013. Geoinformatics and water-erosion processes. Geomorphology 183: 1-4.

USDA Soil Conservation Service, 1972. Section 4. Hydrology. W: National Engineering Handbook, US. Department of Agriculture-Soil Conservation Service, Washington.

Vigiak O., Malagó A., Bouraoui F., Vanmaercke M., Poesen J., 2015. Adapting SWAT hillslope erosion model to predict sediment concentrations and yields in large Basins. Science of the Total Environment 538: 855-875.

Williams J.R., 1975. Sediment-yield prediction with universal equation using runoff energy factor. W: Present and prospective technology for predicting sediment yield and sources: Proceedings of the sediment-yield workshop, USDA Sedimantation Lab., Oxford: 244-252.

Williams J.R., 1980. SPNM, a model for predicting sediment, phosphorus, and nitrogen yields from agricultural basins. Water Resources Bulletin 16: 843-848.

Zwoliński Zb., 1989. Geomorficzne dostosowywanie się koryta Parsęty do aktualnego reżimu rzecznego. Dokumentacja Geograficzna 3-4: $1-144$.

Zwoliński Zb., 2010. Przedmowa. W: GIS - woda w środowisku, Zb. Zwoliński (red.), Wydawnictwo Naukowe Bogucki, Poznań: 9-10.

Zwoliński Zb., 2011. Globalne zmiany klimatu i ich implikacje dla rzeźby Polski. Landform Analysis 15: 5-15. 